\title{
THE EFFECT OF SOME FACTORS ON EXPRESSION OF GENE ENCODING ENDOGLUCANASE FROM DNA METAGENOME OF BINH CHAU HOT SPRING IN Escherichia coli
}

\author{
Tran Thanh Thuy, Lai Thi Hong Nhung, Tran Dinh Man, \\ Le Thi Thanh Xuan, Nguyen Kim Thoa* \\ Institute of Biotechnology, VAST, Vietnam \\ Received 3 April 2019, accepted 28 May 2019
}

\begin{abstract}
Expression of microbial target genes in Escherichia coli is broadly used due to its advantages namely: well established system, easy to manipulate, a huge biomass, high level productivity, safe and inexpensive to grow. Metagenomic technique has been applying in Vietnam recently for effective mining of uncultured gene resources, especially in endemic mini-ecologies such as hot springs where the cell densities are low. DNA metagenome of Binh Chau hot spring was isolated and sequenced by Illumia Hiseq ${ }^{\mathrm{TM}}$. Based on analyses of databases of cellulase-encoded genes, denovogenes 18736 gene sequence for thermal endoglucanase was selected for expression in $E$. coli. In this paper, some factors for expression of endoglucanase have been investigated. The results show that appropriate gene expression conditions are: Expression performed in E. coli C43 (DE3) on TB medium at $30^{\circ} \mathrm{C}$ with $0.25 \mathrm{mM}$ of IPTG as inducer, the culture volume of $20 \%$ compared with the bottle volume and the expression time is $42-48$ hours. In this condition, the biomass production and soluble enzyme activity can reached up to $5.54-5.58 \mathrm{~g} / \mathrm{L}$ and $1.92-1.98 \mathrm{U} / \mathrm{mL}$, respectively. Our results show the prospect of exploiting microbial genes without culture.
\end{abstract}

Keywords: Binh Chau hot spring, DNA-metagenomic, E. coli C43(DE3), gene expression, recombinant endoglucanase, thermostable enzyme.

Citation: Tran Thanh Thuy, Lai Thi Hong Nhung, Tran Dinh Man, Le Thi Thanh Xuan, Nguyen Kim Thoa, 2019. The effect of some factors on expression of gene encoding endoglucanase from DNA metagenome of Binh Chau hot spring in Escherichia coli. Tap chi Sinh hoc, 41(2): 111-118. https://doi.org/10.15625/0866-7160/v41n2.13726.

*Corresponding author email: nkthoa@ibt.ac.vn

C2019 Vietnam Academy of Science and Technology (VAST) 


\title{
MỘT SỐ ĐIỀU KIỆN ẢNH HƯỞNG ĐẾN QUÁ TRİNH BIỂU HIỆN GEN MÃ HÓA ENDOGLUCANASE TƯ DNA METAGENOME CỦA SUỐI NƯỚC NÓNG BÌNH CHÂU TRONG Escherichia coli
}

\author{
Trần Thanh Thủy, Lại Thị Hồng Nhung, Trần Đình Mấn, \\ Lê Thị Thanh Xuân, Nguyễn Kim Thoa*
}

Viện Công nghệ sinh học, Viện Hàn lâm Khoa học và Công nghệ Việt Nam, Việt Nam

Ngày nhận bài 3-4-2019, ngày chấp nhận, ngày chấp nhận 28-5-2019

\section{TÓM TẮT}

Quá trình biểu hiện các gen đích của vi sinh vật trong tế bào Escherichia coli vẫn được sử dụng rộng rãi trong các nghiên cứu trên thế giới do các ưu điểm của hệ thống này như lượng sinh khối lớn, tốc độ biểu hiện lớn, điều kiện biểu hiện tương đối đơn giản và dễ kiểm soát. Trong những năm gần đây, kỹ thuật metagenomic đã được áp dụng tại Việt Nam để khai thác hiệu quả nguồn gen vi sinh vật không thông qua nuôi cấy, đặc biệt tại các khu hệ sinh thái nhỏ như suối nước nóng nơi có mật độ vi sinh vật rất thấp. Chúng tôi đã tách chiết DNA metagenome của suối nước nóng Bình Châu, giải trình tự toàn bộ DNA metagenome bằng hệ thống Illumina Hiseq ${ }^{\mathrm{TM}}$ để tiếp cận nguồn gen VSV của hệ sinh thái này. Phân tích cơ sở dữ liệu các gen mã hoá cho cellulase, trình tự gen có mã số [denovogenes]_18736 mã hoá cho endoglucanase bền nhiệt được lựa chọn để biểu hiện trong tế bào $E$. coli. Trong khuôn khổ bài báo này, một số điều kiện để biểu hiện endoglucanase đã được khảo sát và kết quả cho thấy điều kiện biểu hiện gen thích hợp được thực hiện trong dòng $E$. coli C43(DE3), thể tích dịch nuôi cấy chiếm $20 \%$ so với thể tích bình, nồng độ $\mathrm{IPTG} 0,25 \mathrm{mM}$, nhiệt độ $30^{\circ} \mathrm{C}$, thời gian biểu hiện 42-48 giờ. Sinh khối khô của chủng $E$. coli C43(DE3) tái tổ hợp đạt 5,54-5,58 g/L; endoglucanase tái tổ hợp ở dạng tan có hoạt độ đạt 1,92-1,98 U/mL. Kết quả nghiên cứu cho thấy triển vọng khai thác các gen của vi sinh vật không thông qua nuôi cấy.

Từ khóa: Biểu hiện gen, DNA-Metagenomic, E. coli C43(DE3), Endoglucanase tái tổ hợp, enzyme bền nhiệt, suối nước nóng Bình Châu.

*Địa chỉ liên hệ email: hautd@ hnue.edu.vn

\section{MỞ ĐẦU}

Bản thân các tế bào Escherichia coli được coi như một nhà máy có thiết kế hoàn chỉnh và được sử dụng rộng rãi nhất trong hệ thống biểu hiện các protein tái tổ hợp. Bởi vậy, có nhiều kỹ thuật phân tử và phương pháp để nâng cao hiệu suất biểu hiện các protein dung hợp như hệ thống các vector biểu hiện, các dòng tế bào kiến tạo và các định hướng nuôi cấy (Rosano \& Ceccarelli, 2014). Không còn nghi ngờ gì nữa khi quá trình sản xuât các protein tái tổ hợp bằng hệ thống tế bào vi sinh vật là một bước tiến lớn trong ngành hoá sinh. Uu điểm của việc sử dụng $E$. coli làm vật chủ đã được biết đến, bao gồm (i) Tốc độ sinh trưởng nhanh. Khi nuôi trong môi trường cơ bản chứa glucose và muối, thời gian nhân đôi thế hệ khoảng 20 phút (Sezonov et al., 2007); (ii) Mật độ tế bào lớn. Theo lý thuyết, mật độ tế bào có thể đạt được đến $200 \mathrm{~g}$ sinh khối khô/L hoặc $1 \times 10^{13} \mathrm{CFU} / \mathrm{mL}$ (Shiloach \& Fass, 2005). Tuy nhiên, sự tăng trưởng theo cấp số nhân trong môi trường giàu dinh dưỡng không đạt được đến mật độ theo lý thuyết. 
Thông thường, mật độ chỉ đạt được giới hạn trên $<1 \times 10^{10} \mathrm{CFU} / \mathrm{mL}$ khi nuôi cấy trong môi trường $\mathrm{LB}$ ở $37^{\circ} \mathrm{C}$ (Sezonov et al., 2007); (iii) Thành phần môi trường nuôi cấy thường là các hóa chất sẵn có, không đắt tiền; (iv) Quá trình biến nạp DNA ngoại lai vào tế bào thường nhanh và hiệu quả. Cho đến nay, các kỹ thuật và phương pháp nhằm tiếp tục nâng cao hiệu suất biểu hiện protein dung hợp ở tế bào $E$. coli ngày càng được hoàn thiện, từ việc cải tiến các plasmid mang vùng sao chép đa bản sao, vùng promoter mạnh, gắn các đuôi ái lực để thuận tiện cho việc tinh chế protein đến việc lựa chọn các dòng $E$. coli phù hợp làm vật chủ cho quá trình biểu hiện protein tái tổ hợp và các yếu tố ảnh hưởng đến quá trình nuôi cấy như nồng độ chất cảm ứng, độ thông khí, nhiệt độ biểu hiện, thời gian biểu hiện,... (Rosano \& Ceccarelli, 2014). Đối với mối loại protein tái tổ hợp sẽ có tập hợp các điều kiện phù hợp cho hiệu suất biểu hiện cao nhất.

Endoglucanase (EC 3.2.1.4) là enzyme quan trọng nhất trong hệ enzyme thuỷ phân cellulose. Quá trình thuỷ phân cellulose thường diễn ra trong thời gian dài ở điều kiện đặc biệt như nhiệt độ, áp suất cao, trong môi trường kiềm hoặc axit. Chính vì vậy, các enzyme có tính chất bền nhiệt, chịu kiềm/axit trở thành các đối tượng được ưu tiên tìm kiếm trong các khu hệ vi sinh vật. Các enzyme bền nhiệt thường được thu nhận từ các vi sinh vật ưa nhiệt, có mặt tại các vùng địa nhiệt (suối nước nóng, miệng núi lửa, giàn khoan dầu khí...). Suối nước nóng Bình Châu là suối lộ thiên có nhiệt độ nóng thứ hai ở Việt Nam với nhiệt độ miệng giếng phun khoảng $82^{\circ} \mathrm{C}$, bao quanh là khu vực rừng tràm nguyên sinh, do đó khu hệ sinh thái này có nhiều tiềm năng để khai thác các gen mã hoá cho các enzyme bền nhiệt. Cũng như các hệ sinh thái đặc biệt khác, mật độ vi sinh vật tại suối nước nóng Bình Châu rất thấp, do đó để tiếp cận nguồn vật liệu di truyền quý giá này, kỹ thuật metagenomic được xem là lựa chọn tối ưu nhất.

Từ các công bố trên thế giới, nhiều gen mã hoá cho endoglucanase đã được tách dòng và biểu hiện bằng kỹ thuật metagenomic. Gần đây, nhóm nghiên cứu của Gupta et al. (2017) đã tách dòng và biểu hiện endoglucanase bền nhiệt và kiềm tính từ suối nước nóng Puga ở Ladakh thông qua thư viện DNA metagenome. Liew et al. (2018) đã tách dòng trực tiếp được gen mã hoá cellulase chịu nhiệt cao có chiều dài 930 bp, mã hoá cho 309 axit amin từ DNA metagenome của suối nước nóng Ulu Slim. Nhóm tác giả đã biểu hiện thành công trong $E$. coli BL21(DE3) với hệ vector $\mathrm{pET} 28 \mathrm{a}(+)$. Ở Việt Nam, nhóm nghiên cứu của Trương Nam Hải đã biểu hiện thành công endoglucanase mới từ DNA metagenome ruột mối Coptotermes gestroi trong tế bào E. coli BL21 (Nguyễn Thị Thảo, 2015). Ngoài ra, các endoglucanase bền nhiệt chủ yếu được thu nhận thông qua các chủng vi khuẩn phân lập được từ các suối nước nóng khác nhau (Man et al., 2012, Nguyễn Kim Thoa và nnk., 2015).

Với mục tiêu thu nhận endoglucanase bền nhiệt mới, chúng tôi đã giải trình tự và phân tích cơ sở dữ liệu DNA metagenome của suối nước nóng Bình Châu. Trong số các gen mã hoá cho nhóm enzyme cellulase, trình tự gen mã số [denovogenes]_18736 có tiềm năng chịu nhiệt cao $\left(\mathrm{Tm}>65^{\circ} \mathrm{C}\right)$ được lựa chọn và tổng hợp hoá học tại Công ty Phusa Biochem (Việt Nam). Trình tự này đã được khuếch đại và đưa vào hệ vector biểu hiện $\mathrm{pET} 17 \mathrm{~b}$ (Novagen), biểu hiện ở dạng protein tan trong tế bào $E$. coli JM109(DE3) (dữ liệu không công bố). Tuy nhiên, lượng protein biểu hiện ban đầu còn khá thấp nên việc tiếp tục nghiên cứu thay đổi một số điều kiện nhằm nâng cao hiệu suất biểu hiện là cần thiết. Bài báo này trình bày quá trình khảo sát một số yếu tố như: dòng tế bào $E$. coli, độ thông khí, nồng độ chất cảm ứng... tác động đến hiệu suất biểu hiện endoglucanase tái tổ hợp.

\section{VÂT LIỆU VÀ PHƯƠNG PHÁP NGHIÊN CúU}

Vật liệu sử dụng trong nghiên cứu này bao gồm: Vector pET17b (Novagen) mang đoạn ORF của trình tự gen [denovogenes]_18736; chủng E. coli JM109(DE3) (Promega), và chủng E. coli $\mathrm{C} 43(\mathrm{DE} 3)$ (Lucigen). Các hoá chất cần cho quá trình biểu hiện: IPTG, ampicillin, Bacto Tryptone, cao nấm men, cao thịt, $\mathrm{K}_{2} \mathrm{HPO}_{4}, \mathrm{KH}_{2} \mathrm{PO}_{4}, \mathrm{NaCl}$, glycerol được 
cung cấp bởi các công ty hoá chất quốc tế, có độ tinh khiết cao.

\section{Chuẩn bị tế bào khả biến}

Tế bào $E$. coli khả biến được chuẩn bị theo phương pháp được mô tả bởi Sambrook \& Russell (2001).

Biến nạp plasmid pET17b mang ORF của trình tự gen [denovogenes]_18736 (pET17b_18736) vào tế bào $E$. Coli

Trộn plasmid pET17b_18736 (10-15 ng) vào tế bào $E$. coli khả biến đã được chuẩn bị ở trên trước khi chuyển vào cuvette nhựa có chiều rộng khe $0,1 \mathrm{~cm}$ (Peqlab). Cuvette được giữ lạnh trên đá trước khi xung điện ở điện thế $1.800 \mathrm{~V} / \mathrm{cm}$, trong 1 giây. Tế bào được hồi phục ở $37^{\circ} \mathrm{C}$, lắc $200 \mathrm{rpm}, 1$ giờ trong môi trường SOC. Dịch tế bào được cấy trải trên môi trường $\mathrm{LB}+$ ampicillin cho đến khi thu được khuẩn lạc riêng rẽ. Các khuẩn lạc được sử dụng để kiểm tra đoạn gen ngoại lai bằng kỹ thuật PCR-colony.

\section{Biểu hiện endoglucanase tái tổ hợp}

Các chủng E. coli có mang plasmid pET17b_18736 được nhân giống trong môi trường $\mathrm{LB}$ lỏng + ampicillin ở $37^{\circ} \mathrm{C}, 200 \mathrm{rpm}$ tù̀ 16-18 giờ. Giông được chuyển sang bình tam giác $500 \mathrm{~mL}$ có chứa $100 \mathrm{~mL}$ môi trường biểu hiện + ampicillin $(100 \mu \mathrm{g} / \mathrm{mL})$ với tỷ lệ $1 \%$ (v/v). Lắc bình ở điều kiện $200 \mathrm{rpm}, 37^{\circ} \mathrm{C}$ cho đến khi $\mathrm{OD}_{600}$ của dịch nuôi cấy đạt $0,6-0,8$, bổ sung $1 \mathrm{mM}$ isopropyl- $\beta$-D-thiogalactoside (IPTG) trước khi hạ nhiệt độ xuống còn $30^{\circ} \mathrm{C}$. Tiếp tục nuôi lắc $200 \mathrm{rpm}$ trong 48 giờ. Loại bỏ dịch nổi, thu tế bào bằng ly tâm $10.000 \mathrm{rpm}$. Bảo quản sinh khối ở $-20^{\circ} \mathrm{C}$.

\section{Xác định khối lượng sinh khối khô}

Sấy khô sinh khối ở $105^{\circ} \mathrm{C}$ đến khối lượng không đổi để xác định khối lượng sinh khối khô.

\section{Thu nhận enzyme thô}

Sinh khối tươi được rửa và hòa lại vào trong dung dịch đệm phá tế bào $(50 \mathrm{mM}$ Tris/HCl, pH 8,5; 1 mM EDTA; $100 \mathrm{mM}$ $\mathrm{NaCl} ; 0,1 \mathrm{mM}$ DTE và $1 \mathrm{mM}$ PMSF). Siêu âm phá tế bào. Dịch enzyme thô được thu nhận bằng ly tâm $14.000 \mathrm{rpm}$ trong 1 giờ.

\section{Định tính endoglucanase}

Chuẩn bị đĩa petri $\mathrm{CMC}(1 \%)$ có đục lỗ đường kính $10 \mathrm{~mm}$. Nhỏ dịch enzyme $(100 \mu \mathrm{L})$ vào lỗ. Đặt đĩa ở $4^{\circ} \mathrm{C}$ trong 4 giờ để dịch enzyme khuếch tán vào thạch trước khi chuyển vào tủ ấm $55^{\circ} \mathrm{C}, 16-18$ giờ. Hoạt tính endoglucanase được đánh giá bằng đường kính vòng phân giải sau khi nhuộm bằng dung dịch Congo red.

\section{Xác định hoạt độ endoglucanase}

Hoạt độ endoglucanase được xác định theo phương pháp của Ghose (1987). Lượng đường sinh ra được định lượng bằng dung dịch DNS theo phương pháp của Miller (1959). Một đơn vị endoglucanase (U) được định nghĩa là lượng enzyme cần thiết xúc tác phân giải cơ chất để giải phóng ra $1 \mu \mathrm{M}$ đường khử trong thời gian một phút ở điều kiện nhiệt độ $55^{\circ} \mathrm{C}$.

Ảnh hưởng của các yếu tố đến hiệu suất biểu hiện endoglucanase

\section{Lụa chọn chủng chủ biểu hiện}

Hai dòng tế bào $E$. coli C43(DE3) (Lucigen) và E. coli JM109 (DE3) (Promega) được sử dụng làm chủng chủ để biểu hiện endoglucanase tái tồ hợp. Plasmid pET17b_18736 được biến nạp vào 2 dòng tế bào khả biến bằng phương pháp xung điện. Các tế bào $E$. coli tái tổ hợp được nuôi cấy và xác định khối lượng sinh khối cũng như hoạt tính của enzyme dung hợp.

\section{Lụa chọn môi truờng biểu hiện}

Chủng E. coli C43(DE3) tái tổ hợp mang vector pET17b_18736 được nhân giống trên môi trường $\mathrm{LB}$ trước khi chuyển sang biểu hiện trên 3 loại môi trường $\mathrm{NB}, \mathrm{LB}$ và $\mathrm{TB}$. Hiệu suất biểu hiện được đánh giá thông qua khối lượng sinh khối và hoạt tính của enzyme dung hợp.

\section{Độ thoáng khí}

Giống khởi động của chủng E. coli C43(DE3) tái tổ hợp được chuyển vào các bình tam giác (thể tích $500 \mathrm{~mL}$ ) chứa môi trường $\mathrm{TB}$ với các thể tích khác nhau 50-300 $\mathrm{mL}$ (tương ứng 10-60\% thể tích bình). Quá trình biểu hiện được thực hiện ở $30^{\circ} \mathrm{C}, 200$ 
rpm trong 48 giờ. Hiệu suất biểu hiện được đánh giá thông qua khối lượng sinh khối và hoạt tính của enzyme dung hợp.

\section{Nồng độ IPTG}

Nuôi cấy chủng $E$. coli $\mathrm{C} 43(\mathrm{DE} 3)$ tái tổ hợp trên môi trường $\mathrm{TB}$ cho đến khi $\mathrm{OD}_{600}$ đạt $0,6-0,8$, bổ sung IPTG với các nồng độ $0,25-$ $1,5 \mathrm{mM}$. Hiệu suất biểu hiện được đánh giá thông qua khối lượng sinh khối và hoạt tính của enzyme dung hợp.

\section{Động thái sinh trưởng và sinh endoglucanase}

Chủng E. coli $\mathrm{C} 43(\mathrm{DE} 3)$ tái tổ hợp được nuôi trong bình tam giác $(500 \mathrm{~mL})$ có chứa $100 \mathrm{~mL}$ môi trường TB. Quá trình biểu hiện được thực hiện sau khi cảm ứng $0,25 \mathrm{mM}$ IPTG, $30^{\circ} \mathrm{C}, 200 \mathrm{rpm}$. Mẫu được lấy sau mỗi 6 giờ trong 48 giờ để xác định khối lượng sinh khối và hoạt tính của enzyme dung hợp.

\section{KẾT QUẢ VÀ THẢO LUẬN}

\section{Lựa chọn chủng chủ biểu hiện endoglucanase tái tổ hợp}

Plasmid pET17b_18736 được biến nạp vào hai dòng tế bào $E$. coli $\mathrm{C} 43(\mathrm{DE} 3)$ và $E$. coli JM109(DE3) để đánh giá mức độ biểu hiện endoglucanase của các chủng chủ khác nhau.

Sau 48 giờ cảm ứng bằng $1 \mathrm{mM}$ IPTG, khối lượng sinh khối khô và hoạt tính enzyme được xác định cho thấy khả năng sinh trưởng của hai chủng tái tổ hợp tương đương nhau (khối lượng sinh khối khô của chủng tái tổ hợp E. coli $\mathrm{C} 43(\mathrm{DE} 3)$ và $\mathrm{JM} 109(\mathrm{DE} 3)$ lần lượt đạt $4,43 \mathrm{~g} / \mathrm{L}$ và $4,36 \mathrm{~g} / \mathrm{L}$ ) nhưng hoạt tính endoglucanase của chủng $E$. coli $\mathrm{C} 43(\mathrm{DE} 3)$ tái tồ hợp cao hơn, đạt $0,79 \mathrm{U} / \mathrm{mL}$ trong khi enzyme của chủng $E$. coli JM109(DE3) tái tổ hợp chỉ đạt có $0,56 \mathrm{U} / \mathrm{mL}$ (hình 1-2). Tất cả các mẫu đối chứng (không cảm ứng với IPTG) đều không có hoạt tính. Như vậy có thể thấy, endoglucanase tái tổ hợp đã được biểu hiện ở dạng tan. Chủng E. coli C43(DE3) được Miroux \& Walker (1996) phát triển từ quá trình sàng lọc các biến chủng của dòng $E$. coli BL21(DE3) để biểu hiện vượt ngưỡng các protein màng. Uu điểm của dòng $E$. coli C43(DE3) so với dòng gốc $E$. coli
BL21(DE3) ở chỗ hạn chế tỷ lệ chết của tế bào khi biểu hiện quá mức protein dung hợp, do đã được đột biến tại hai điểm trên vùng -10 của promoter lacUV5. Trong khi đó, dòng tế bào $E$. coli JM109(DE3) là chủng được dùng chủ yếu trong các chiến lược tách dòng gen. Từ kết quả này, chủng $E$. coli $\mathrm{C} 43(\mathrm{DE} 3)$ tái tổ hợp được chọn cho các nghiên cứu tiếp theo.

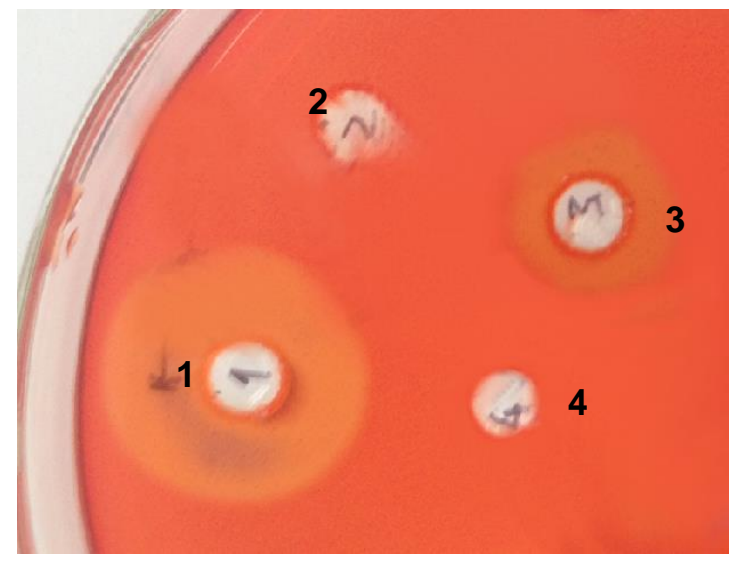

Hình 1. Khả năng phân giải $\mathrm{CMC}$ của các chủng tái tổ hợp. 1: E. coli $\mathrm{C} 43(\mathrm{DE} 3)$ cảm ứng IPTG; 2: $E$. coli $\mathrm{C} 43$ (DE3) không cảm ứng IPTG; 3: E. coli JM109 cảm ứng IPTG; 4: E. coli JM109 không cảm ứng IPTG

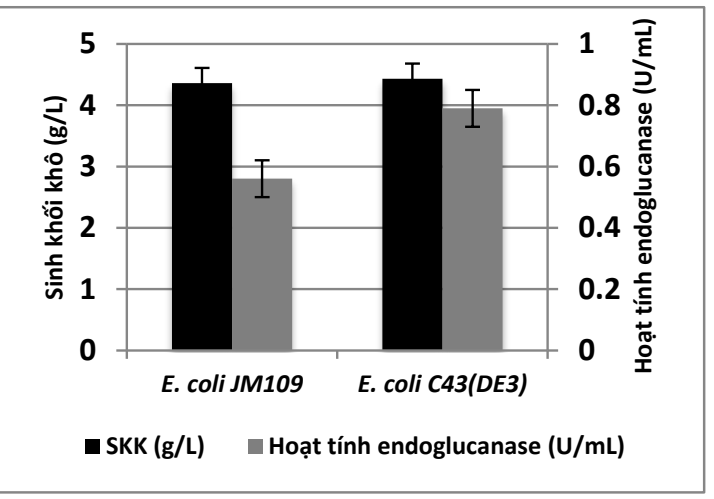

Hình 2. Ảnh hưởng của chủng chủ lên quá trình sinh trưởng và biểu hiện endoglucanase tái tổ hợp

\section{Lựa chọn môi trường biểu hiện endoglucanase tái tổ hợp}

Chủng E. coli $\mathrm{C} 43(\mathrm{DE} 3)$ tái tổ hợp mang vector pET17b_18736 được nuôi trên các môi trường $\mathrm{NB}, \overline{\mathrm{LB}}$ và $\mathrm{TB}$ để biểu hiện 
endoglucanase. Sau 48 giờ biểu hiện ở $30^{\circ} \mathrm{C}$, môi trường $\mathrm{TB}$ là môi trường cho sinh trưởng và biểu hiện hoạt tính enzyme tốt nhất (đạt $4,42 \mathrm{~g} / \mathrm{L}$ và $0,79 \mathrm{U} / \mathrm{mL}$ ), sau là môi trường $\mathrm{LB}$ và cuối cùng là môi trường $\mathrm{NB}$ (hình 3 ). Môi trường $\mathrm{NB}$ và $\mathrm{LB}$ là môi trường được sử dụng phổ biến nhất để nuôi cấy $E$. coli do chứa các thành phần dinh dưỡng dễ hấp thụ ở giai đoạn tăng sinh sớm. Tuy nhiên, các môi trường này không phải là lựa chọn tốt nhất để biểu hiện các protein dung hợp vì chứa rất ít carbohydrate và các ion kim loại hóa trị II (Sezonov et al., 2007). Trong khi đó, thành phần môi trường $\mathrm{TB}$ có hàm lượng cao nấm men gấp đôi so với thành phần môi trường LB và $\mathrm{NB}$, vì vậy khi nuôi cây $E$. coli trong môi trường $\mathrm{TB}$ sẽ cho mật độ tế bào cao hơn (Studier, 2005). Mặt khác, các chủng $E$. coli tái tổ hợp khi biểu hiện protein dung hợp cần một lượng phosphate rất lớn, điều này chỉ có môi trường $\mathrm{TB}$ đáp ứng được. Hơn nữa, môi trường $\mathrm{TB}$ có chứa glycerol cũng đóng vai trò cảm ứng biểu hiện protein được điều khiển bởi lac promoter (Studier, 2014).

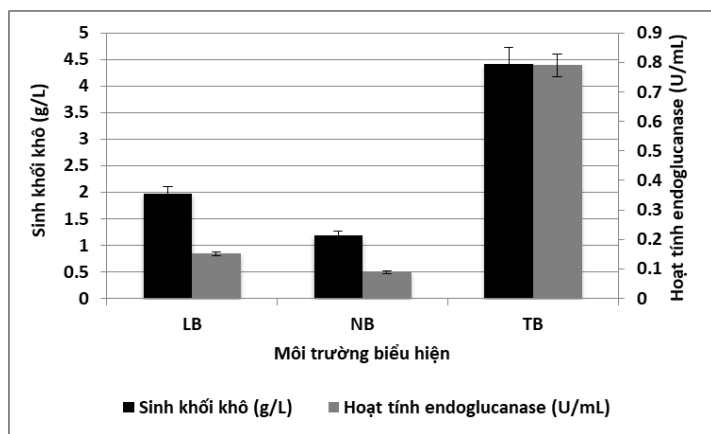

Hình 3. Ảnh hưởng của môi trường nuôi cấy lên sinh trưởng và sinh hoạt tính endoglucanase của chủng E. coli $\mathrm{C} 43(\mathrm{DE} 3)$ tái tổ hợp

Ảnh hưởng của độ thoáng khí đến biểu hiện endoglucanase tái tổ hợp

E. coli là vi khuẩn hiếu khí, do vậy, lượng oxy hoà tan trong môi trường nuôi cấy là một yếu tố quan trọng, có ảnh hưởng rõ rệt đến sự sinh trưởng (O'Beirne \& Hamer, 2000, Losen et al., 2004). Để nâng cao hàm lượng sinh khối tế bào cũng như hoạt tính enzyme dung hợp, người ta có thể điều chỉnh chỉ số oxy hoà tan bằng cách tăng tốc độ lắc hoặc giảm thể tích dịch nuôi trong bình. Trong nghiên cứu này, chúng tôi đã khảo sát ảnh hưởng của 4 thể tích dịch nuôi trên cùng một loại bình tam giác $(500 \mathrm{~mL})$. Kết quả nghiên cứu trong hình 4 cho thấy: thể tích dịch nuôi cấy có ảnh hưởng đến quá trình sinh trưởng và biểu hiện enzyme dung hợp. Mật độ tế bào của chủng tái tổ hợp tỉ lệ nghịch với thể tích nuôi cấy. Trong 4 điều kiện khảo sát, mật độ tế bào đạt cao nhất $(6,42$ $\mathrm{g} / \mathrm{L})$ khi thể tích nuôii cấy chiếm $10 \%$ thể tích bình và giảm dần khi tăng thể tích dịch nuôi cấy. Trong khi đó, hoạt tính endoglucanase tái tổ hợp cao nhất ở bình chứa thể tích dịch nuôi chiếm 20\% (hoạt tính đạt $1,87 \mathrm{U} / \mathrm{mL}$ ). Kết quả nghiên cứu này cũng phù hợp với công bố của Rosano \& Ceccarelli (2014), do đó tỷ lệ $20 \%$ được lựa chọn là tỷ lệ thông khí thích hợp cho biểu hiện enzyme dung hợp.

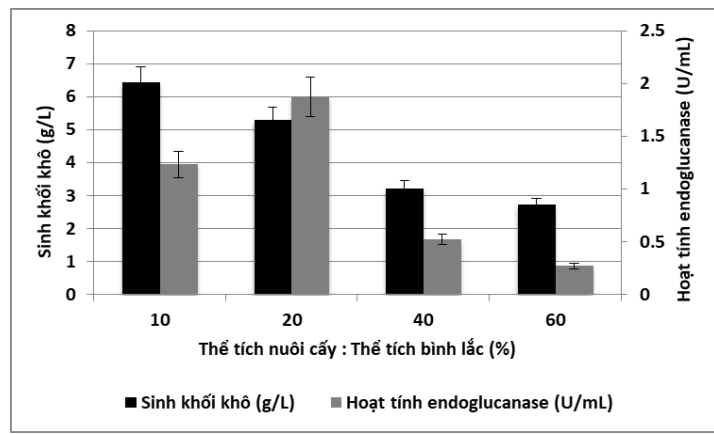

Hình 4. Ảnh hưởng của độ thoáng khí lên sinh trưởng và sinh hoạt tính endoglucanase của chủng E. coli C43(DE3) tái tổ hợp

\section{Ảnh hưởng của nồng độ IPTG đến biểu hiện endoglucanase tái tổ hợp}

IPTG là chất cảm ứng cho T7-promoter của hầu hết các vector biểu hiện thuộc hệ thống pET. Trong nghiên cứu này, chúng tôi khảo sát ảnh hưởng của nồng độ IPTG từ 0,25 $-1,5 \mathrm{mM}$ lên quá trình biểu hiện endoglucanase tái tồ hợp. Kết quả thu được cho thấy ở nồng độ IPTG $0,25 \mathrm{mM}$, chủng $E$. coli C43(DE3) tái tổ hợp biểu hiện endoglucanase cao nhất, đạt $1,93 \mathrm{U} / \mathrm{mL}$ (hình 5), tương tự với công bố của Aftab và cộng sự (2012) thu nhận được endoglucanase tái tổ hợp cao nhất $1,5 \mathrm{U} / \mathrm{mL}$ khi cảm ứng IPTG ở nồng độ $0,3-0,4 \mathrm{mM}$. 


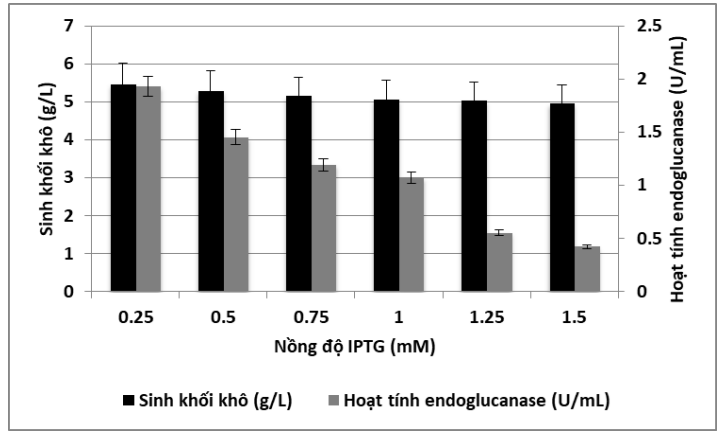

Hình 5. Ảnh hưởng nồng độ IPTG cảm ứng lên sinh trưởng và biểu hiện endoglucanase_18736 của chủng tái tổ hợp

Động thái sinh trưởng và biểu hiện endoglucanase dung hợp của chủng $E$. coli C43(DE3) tái tổ hợp

Dưới các điều kiện nuôi cấy được lựa chọn ở trên, quá trình sinh trưởng và biểu hiện endoglucanase tái tổ hợp của chủng $E$. coli C43(DE3) mang plasmid pET17b_18736 vào pha cân bằng sau 42-48 giờ nuôi cấy, phù hợp với điều kiện sinh lý của vi khuẩn nói chung và loài $E$. coli nói riêng (Ryan et al., 1996). Trong khoảng thời gian này, sinh khối khô đạt giá trị dao động trong khoảng 5,54-5,58 g/L; sinh tổng hợp endoglucanase đạt 1,921,98 U/mL (hình 6).

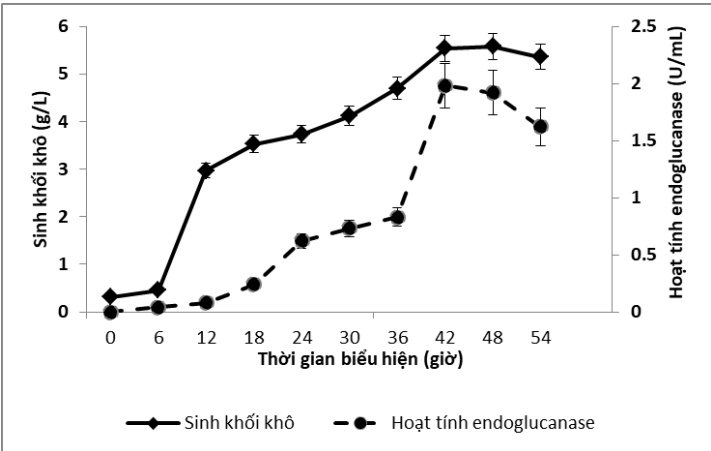

Hình 6. Động thái sinh trưởng và sinh endoglucanase của chủng $E$. coli C43(DE3) tái tổ hợp

\section{KẾT LUẬN}

Endoglucanase tái tổ hợp được biểu hiện tốt nhất trong dòng $E$. coli $\mathrm{C} 43(\mathrm{DE} 3)$. Đã xác định được một số yếu tố ảnh hưởng đến quá trình biểu hiện endoglucanase của chủng $E$. coli $\mathrm{C} 43$ (DE3) tái tổ hợp. Enzyme dung hợp được biểu hiện tốt nhất trong môi trường $\mathrm{TB}$ với thể tích dịch nuôi cấy chiếm $20 \%$ so với thể tích bình, nồng độ IPTG cảm ứng ở 0,25 $\mathrm{mM}$. Hoạt tính enzyme đạt 1,92-1,98 U/mL sau 42-48 giờ với mật độ sinh khối khô đạt $5,54-5,58 \mathrm{~g} / \mathrm{L}$.

Lời cảm ơn: Công trình này được thực hiện với sự hỗ trợ kinh phí của đề tài "Nghiên cứu metagenome của một số hệ sinh thái mini tiềm năng nhằm khai thác các gen mới mã hóa hệ enzyme chuyển hóa hiệu quả lignocellulose", mã số ĐTĐLCN.15/14, Bộ Khoa học và Công nghệ.

\section{TÀI LIỆU THAM KHẢO}

Aftab S., Aftab N., Javed M. M., 2012. Cloning and expression of endo-1,4- $\beta$ glucanase gene from Bacillus licheniformis ATCC 14580 into Escherichia coli BL21 (DE 3). African Journal of Biotechnology, 11(12): 2846-2854.

Ghose T. K., 1987. Measurement of cellulase activities. Pure and Applied Chemistry, 59(2): 257.

Gupta P., Mishra A. K., Vakhlu J., 2017. Cloning and characterization of thermoalkalistable and surfactant stable endoglucanase from Puga hot spring metagenome of Ladakh (J\&K). Int. J. Biol. Macromol., 103: 870-877.

Liew K., Lim C., Chan C., Wei K., Salleh M., Sani R., Chan K.-G., Goh K., 2018. Chapter 16 - Direct Cellulase Gene Amplification From Hot Spring Using the Guidance of 16S rRNA Amplicon Metagenomics A2 - Nagarajan, Muniyandi. Metagenomics Academic Press: 309-325.

Losen M., Frolich B., Pohl M., Buchs J., 2004. Effect of oxygen limitation and medium composition on Escherichia coli fermentation in shake-flask cultures. Biotechnol. Prog., 20(4): 1062-1068.

Man T. D., Thoa N. K., Da N. T., Viet N. Q., 2012. Biologycal characteristics and classification of the thermophilic bacteria 
BML07 strain producing both thermostable amylase and cellulase isolated from MY LAM hot spring. Vietnam Journal of Science and Technology, 50(3): 275-283

Miller G. L., 1959. Use of Dinitrosalicylic Acid Reagent for Determination of Reducing Sugar. Analytical Chemistry, 31(3): 426-428.

Miroux B., Walker J. E., 1996. Overproduction of proteins in Escherichia coli: Mutant hosts that allow synthesis of some membrane proteins and globular proteins at high levels. Journal of Molecular Biology, 260(3): 289-298.

Nguyễn Kim Thoa, Trần Thanh Thủy, Trần Thị Hoa, Mấn T. Đ., 2015. Tiềm năng thu nhận enzyme bền nhiệt từ nhóm vi khuẩn phân lập tại suối nước nóng Bình Châu. Báo cáo Khoa học về Sinh thái và Tài nguyên sinh vật. Hội nghị Khoa học toàn quốc về Sinh thái và Tài nguyên sinh vật lần thứ $6,1234-1238$.

Nguyễn Thị Thảo, 2015. Nghiên cứu gen mã hóa enzyme tham gia thủy phân cellulose từ khu hệ vi khuẩn ruột mối bằng kỹ thuật Metagenomics. Luận án Tiến sĩ, Trường Đại học Khoa học Tự nhiên, Đại học Quốc gia Hà Nội.

O'Beirne D., Hamer G., 2000. Oxygen availability and the growth of Escherichia coli W3110: A problem exacerbated by scale-up. Bioprocess Engineering, 23(5): 487-494.

Rosano G. L., Ceccarelli E. A., 2014. Recombinant protein expression in Escherichia coli: advances and challenges. Frontiers in microbiology, 5: 172-172.

Ryan W., Collier P., Loredo L., Pope J., Sachdev R., 1996. Growth kinetics of Escherichia coli and expression of a recombinant protein and its isoforms under heat shock conditions. Biotechnol. Prog., 12(5): 596-601.

Sambrook J., Russell D. W., 2001. Transformation of E. coli by electroporation. In: Molecular Cloning: A Laboratory Manual. 3rd ed. Cold Spring Harbor, NY, USA: Cold Spring Harbor Laboratory Press, 1119-1122

Sezonov G., Joseleau-Petit D., D'Ari R., 2007. Escherichia coli physiology in LuriaBertani broth. J. Bacteriol., 189(23): 8746-8749.

Shiloach J., Fass R., 2005. Growing E. coli to high cell density--a historical perspective on method development. Biotechnol. Adv., 23(5): 345-357.

Studier F. W., 2005. Protein production by autoinduction in high density shaking cultures. Protein Expr. Purif., 41(1): 207-234.

Studier F. W., 2014. Stable expression clones and auto-induction for protein production in E. coli. Methods Mol. Biol., 1091: 17-32. 